\title{
Spontaneous Intracranial Extradural Hematoma in Sickle Cell Disease
}

\author{
Dominique N'dri Oka ${ }^{1}$ André Tokpa ${ }^{1}$ Alpha Bah ${ }^{2}$ Louis Derou ${ }^{1}$ \\ ${ }^{1}$ Department of Neurosurgery, Yopougon University Hospital, \\ Abidjan, Côte d'Ivoire \\ Address for correspondence Dominique N'dri-Oka, MD, Msc, 21 BP, \\ 632 Abidjan 21, Côte d'Ivoire (e-mail: ndriokad@gmail.com).
}

2 Department of Neurosurgery, Conakry University Hospital, Conakry,

Guinea

J Neurol Surg Rep 2015;76:e97-e99.

\author{
Abstract \\ Keywords \\ - sickle cell disease \\ - crisis \\ - extradural hematoma \\ - subgaleal hematoma
}

Spontaneous extradural hematoma is rare in patients with sickle cell disease. We report a clinical case of a 19-year-old young man with sickle cell anemia who presented a sickle cell crisis complicated by the development of multiple acute extradural and subgaleal hematomas that had not been treated surgically. We discuss the physiopathology of this event. Although it is rare, clinicians should be aware of this phenomenon as part of a spectrum of neurologic complications in these patients.

\section{Introduction}

Sickle cell disease is a qualitative hereditary hemoglobinopathy due to the presence of hemoglobin $S .{ }^{1}$ Its incidence is high in Africa and in African American populations. ${ }^{1,2}$ Neurologic complications of sickle cell disease are rarely described in the medical literature, and their mechanisms are not completely elucidated. The purpose of this study is to contribute to the discussion of a possible mechanism that can explain this spontaneous epidural hematoma in patients with sickle cell disease and highlight the treatment difficulties.

\section{Case Report}

A 19-year-old young man was hospitalized for excruciating headaches. In his history were intermittent polyarthralgias that had been treated as rheumatoid arthritis since he was 10 years old. In December 2009, he experienced violent headaches with insomnia. The next day there was a parietal swelling and exacerbation of the headaches. There was no vomiting, unconsciousness, or epileptic seizure. No history of head trauma was found. This symptomatology involved consultation in a general hospital with no neurosurgical coverage that led him to our institution for definitive neurosurgical management. A physical examination on admission, 4 days after the onset of symptoms, showed normal consciousness and a stiff neck without the Kernig sign or Brudzinski sign.
The patient had a balance disorder associated with parietal subcutaneous swelling on the right side. Splenomegaly was observed.

The cranioencephalic computed tomography (CT) scan showed a median occipital epidural hematoma extending into the posterior fossa with a subgaleal hematoma ( - Fig. 1). Bone windowing revealed calvarial bone expansion suggestive of medullary hemopoiesis ( $\mathbf{- F i g . 2}$ ). An angioscan did not reveal any vascular malformation (-Fig. 3). No cranioencephalic magnetic resonance imaging (MRI) was performed.

On admission, the patient's heart examination showed left ventricular hypertrophy. A complete blood count revealed red blood cell count $4,170,000$ cells $/ \mathrm{mm}^{3}$, hemoglobin level 10.5 $\mathrm{g} / \mathrm{dL}$, hematocrit $26.7 \%$, platelet count 79,000 platelets $/ \mathrm{mm}^{3}$, and white blood cell count 5,980 cells $/ \mathrm{mm}^{3}$. Fibrinogen level was $2.70 \mathrm{~g} / \mathrm{L}$ (normal value is between 2 and $4 \mathrm{~g} / \mathrm{L}$ ). The coagulation profile showed normal prothrombin $100 \%$, activated kaolin time 13.6/13.5 s, and international normalized ratio of 1.0. Antithrombin III was $0.26 \mathrm{~g} / \mathrm{L}$; C-reactive protein was not tested. Urea and creatinine rates were $0.15 \mathrm{~g} / \mathrm{L}$ and $0.6 \mathrm{mg} / \mathrm{L}$, respectively. Hepatic enzyme values were aspartate aminotransferase $5 \mathrm{IU} / \mathrm{L}$ and alanine aminotransferase $23 \mathrm{IU} /$ L. Double heterozygous sickle cell (SC) ( $\mathrm{S}=45 \%, \mathrm{C}=55 \%)$ was diagnosed on hemoglobin electrophoresis.

Hematologic exploration thus concluded in favor of anemia and thrombocytopenia in a sickle cell disease patient. The patient refused transfusion if it would be necessary. Surgery received

November 1, 2014 accepted after revision January 4, 2015

published online

February 25, 2015
DOI http://dx.doi.org/ 10.1055/s-0035-1544953. ISSN 2193-6366. (c) 2015 Georg Thieme Verlag KG
Stuttgart · New York

License terms

(®) $\Theta \circledast$ 

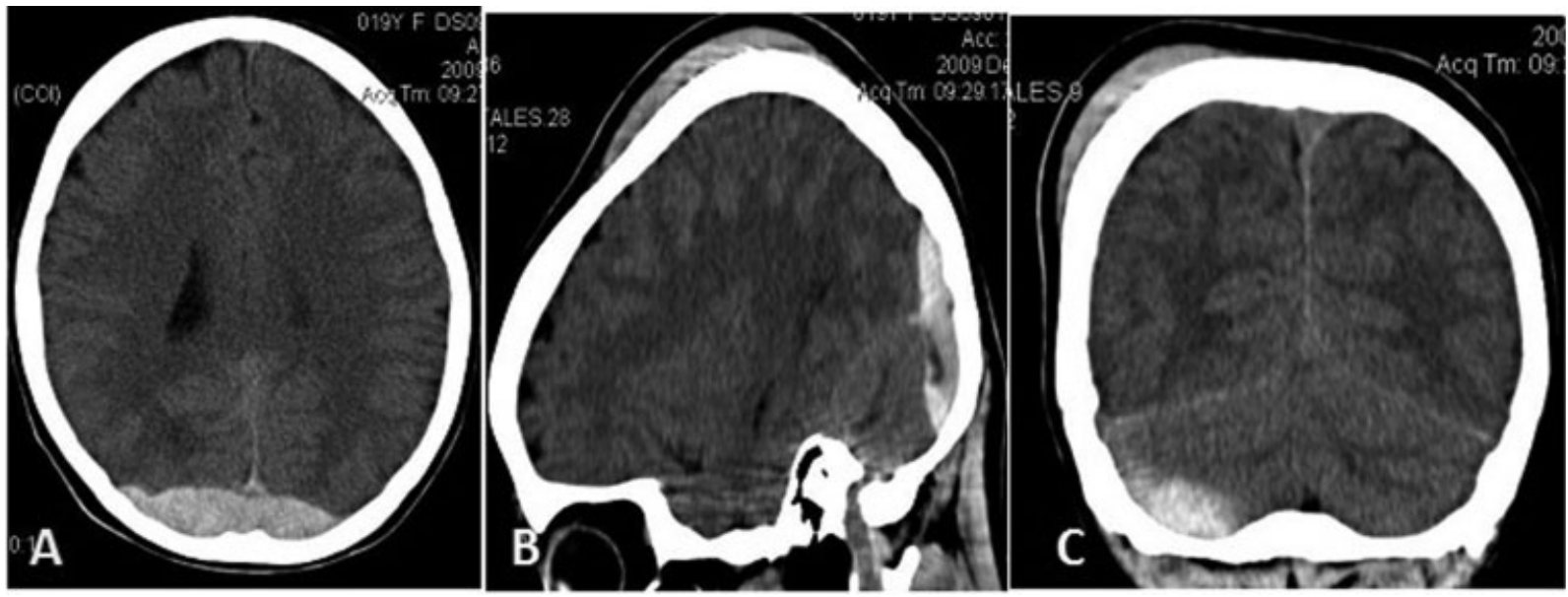

Fig. 1 Axial sagittal and coronal view of computed tomography scan showing multiple extradural hematomas and subgaleal hematoma.

could not be performed, so the patient was treated medically with analgesics and anti-inflammatory and vasodilator drugs. Then he was followed up clinically every month. Headaches decreased and the patient was asymptomatic. At 4-year follow-up, the patient's neurologic outcome was good.

\section{Discussion}

Several cases of spontaneous epidural hematomas have been reported. ${ }^{2,3}$ In most cases, they are caused by infections, dural vascular malformations, and bleeding disorders. ${ }^{4}$ Very few cases of spontaneous intracranial epidural hematomas in patients with sickle cell disease have been reported. ${ }^{1,4,5}$ Since1978, 15 case reports have described the occurrence of spontaneous extradural hematomas as a complication of sickle cell disease. ${ }^{2,3,6-14}$

Pathophysiologic mechanisms of these hematomas are not yet elucidated. A microvascular diploic vaso-occlusive mechanism associated with occlusion of an emissary vein found in a sickle cell disease patient was suggested to be responsible for a spontaneous extradural hematoma. ${ }^{5}$ This mechanism was discussed previously. ${ }^{2}$ All spontaneous extradural hematomas in a patient with sickle cell disease are associated with intraosseous infarction and thrombosis of diploic veins. ${ }^{5}$ These acute complications are related pathophysiologically to vaso-occlusive episodes, complications of hemolytic anemia, and infection. ${ }^{6,15}$ Some of the most devastating complications of this disease involve the cerebrovascular system and are reported to occur at rates of 13 to $17 \%{ }^{16}$ Although the mechanisms of the occurrence of spontaneous bleeding in sickle cell disease are not well known, we have nevertheless identified risk factors, particularly in children, such as blood pressure, blood transfusion, and taking steroids or nonsteroidal anti-inflammatory drugs. ${ }^{5}$ None of these factors was observed in our patient. Regarding the normal prothrombin and activated kaolin time, fibrinogen rate, absence of vascular malformation, infection site, and the presence of a fluctuating thrombocytopenia were observed in various blood counts. It would clearly be the cause of the spontaneous epidural hematoma. However, the focal nature of this bleeding involved local factors. Maybe if MRI had been performed it would have shown cerebral or vault bone skull base infarction that is frequently associated with subgaleal or extradural hematoma. ${ }^{1,6,10,12}$ Vaso-occlusive process in the marrow
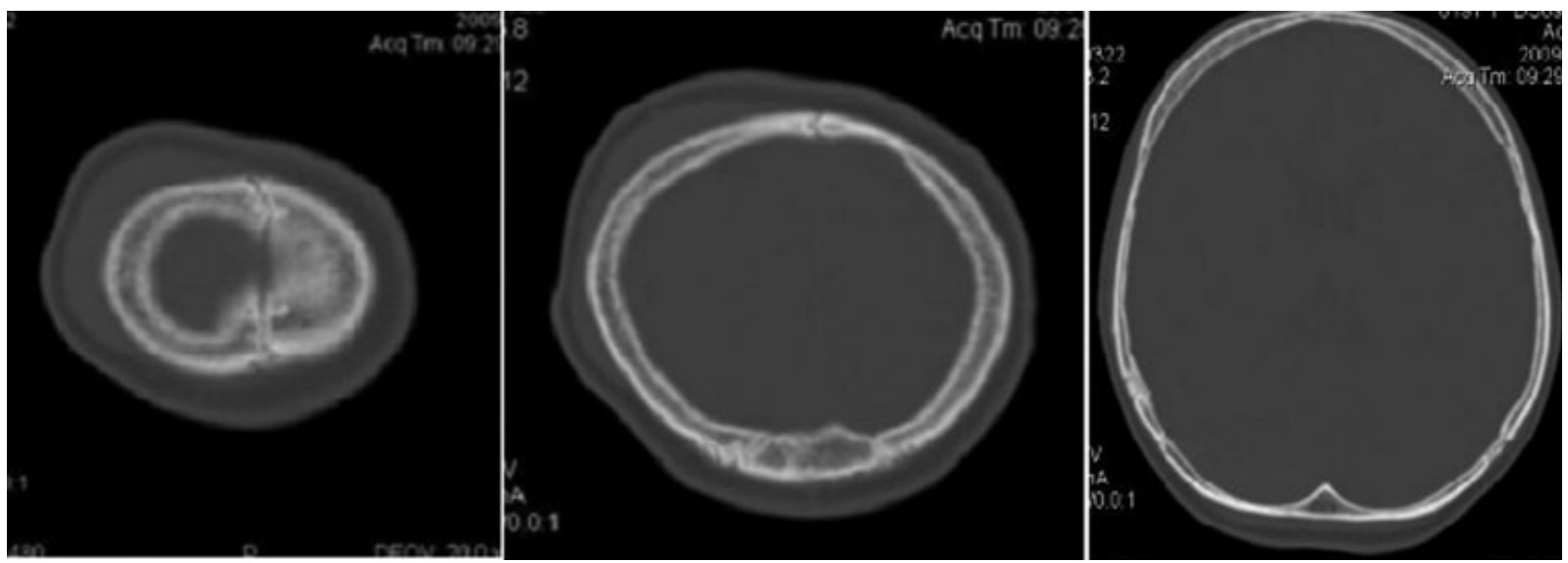

Fig. 2 Axial computed tomography scan bone windows showing diffuse marrow proliferation affecting the frontal and parietal calvaria. Note the widening of the diploic space and thinning of the cortices. 

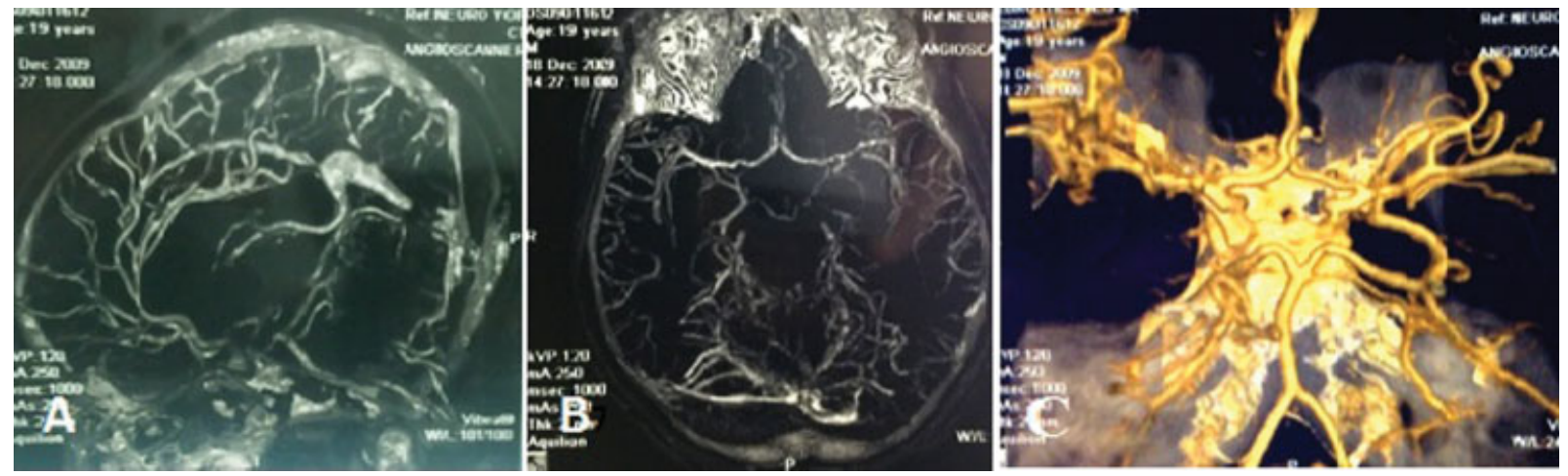

Fig. 3 Angioscan demonstrating the absence of malformation. (A) Sagittal view. (B) Axial view. (C) Arterial three-dimensional reconstruction.

space vault results in bone infarction accompanied by headache. We believe an extradural hematoma could result from thrombocytopenia and osteolytic lesions observed in diploic space. Therefore we agree with some authors in their explanation of hematoma mechanisms. ${ }^{3}$ But other factors like vascular ischemia could not be excluded as a possible mechanism. Finally, the exact mechanism for the epidural hematoma is unknown but probably relates to the skull infarction. The most likely pathophysiologic mechanism is bleeding into the epidural space owing to the disrupted bone margins and vessel walls caused by vaso-occlusion. ${ }^{10}$ The risk of surgical hemorrhage is high because of thrombocytopenia and extradural hematoma anatomical topography.

We opted for medical treatment in our patient because of clinical and CT scan improvement. However, in many cases surgery is required, and in these conditions possible bleeding disorders have to be taken into account, especially thrombocytopenia, and bone lesions that result in intraoperative bleeding. The exact mechanism for the epidural hematoma is unknown, but it probably related to the skull infarction.

\section{Conclusion}

Although a spontaneous extradural hematoma is a rare complication of sickle cell disease, it should be suspected when patients present with a sudden headache or other signs of intracranial hypertension. The search for bone lesions and hemostasis disorders, particularly thrombocytopenia, should be a concern. The existence or the risk of occurrence of the latter complication should guide the therapeutic approach.

\section{Disclaimer}

The authors have no conflicts of interest or financial interests to disclose.

\section{References}

1 Page C, Gardner K, Height S, Rees DC, Hampton T, Thein SL. Nontraumatic extradural hematoma in sickle cell anemia: a rare neurological complication not to be missed. Am J Hematol 2014; 89(2):225-227

2 Kalala Okito JP, Van Damme O, Calliauw L. Are spontaneous epidural haematomas a rare complication? A report of two new cases. Acta Neurochir (Wien) 2004;146:407-410; discussion 410

3 Cabon I, Hladky JP, Lambilliotte A, Cotten A, Dhellemmes P. Uncommon etiology of extradural hematoma [in French]. Neurochirurgie 1997;43(3):173-176

4 Anson JA, Koshy M, Ferguson L, Crowell RM. Subarachnoid hemorrhage in sickle-cell disease. J Neurosurg 1991;75(4): 552-558

5 Strouse JJ, Hulbert ML, DeBaun MR, Jordan LC, Casella JF. Primary hemorrhagic stroke in children with sickle cell disease is associated with recent transfusion and use of corticosteroids. Pediatrics 2006;118(5):1916-1924

6 Arends S, Coebergh JA, Kerkhoffs JL, van Gils A, Koppen H. Severe unilateral headache caused by skull bone infarction with epidural haematoma in a patient with sickle cell disease. Cephalalgia 2011; 31(12):1325-1328

7 Bölke E, Scherer A. Sickle cell disease. CMAJ 2012;184(3):E201

8 Dahdaleh NS, Lindley TE, Kirby PA, Oya H, Howard MA III. A "neurosurgical crisis" of sickle cell disease. J Neurosurg Pediatr 2009;4(6):532-535

9 Karacostas D, Artemis N, Papadopoulou M, Christakis J. Case report: epidural and bilateral retroorbital hematomas complicating sickle cell anemia. Am J Med Sci 1991;302(2): 107-109

10 Mallouh AA, Young M, Hamdan J, Salamah MM. Proptosis, skull infarction, and retro-orbital and epidural hematomas in a child with sickle cell disease. Clin Pediatr (Phila) 1987;26(10): 536-538

11 Naran AD, Fontana L. Sickle cell disease with orbital infarction and epidural hematoma. Pediatr Radiol 2001;31(4):257-259

12 Resar LM, Oliva MM, Casella JF. Skull infarction and epidural hematomas in a patient with sickle cell anemia. J Pediatr Hematol Oncol 1996;18(4):413-415

13 Sangle SA, Lohiya RV, Karne SS, Chugh A. Spontaneous epidural hematoma: a rare complication of sickle cell anemia. Neurol India 2011;59(2):301-302

$14 \mathrm{Ng} \mathrm{WH}$, Yeo TT, Seow WT. Non-traumatic spontaneous acute epidural haematoma-report of two cases and review of the literature. J Clin Neurosci 2004;11(7):791-793

15 Steinberg MH. Management of sickle cell disease. N Engl J Med 1999;340(13):1021-1030

16 Wood DH. Cerebrovascular complications of sickle cell anemia. Stroke 1978;9(1):73-75 